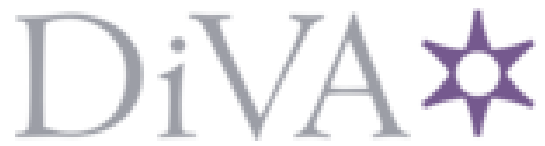

http://www.diva-portal.org

\title{
Postprint
}

This is the accepted version of a chapter published in Handbook of Nordic New Religions.

Citation for the original published chapter:

Frisk, L. (2015)

The New Religious Movements - What Happened to them?: A Study of the Church of Scientology, The Children of God, iskcon, The Unification Church and The Rajneesh Movement and Their Development over Time In: James R. Lewis; Inga Bårdsen Töllefsen (ed.), Handbook of Nordic New Religions (pp. 325-342). London: Brill Academic Publishers https://doi.org/10.1163/9789004292468_021

N.B. When citing this work, cite the original published chapter.

Permanent link to this version:

http://urn.kb.se/resolve?urn=urn:nbn:se:du-16586 


\section{THE NEW RELIGIOUS MOVEMENTS - WHAT HAPPENED TO THEM? A STUDY \\ OF THE CHURCH OF SCIENTOLOGY, THE CHILDREN OF GOD, ISKCON, THE \\ UNIFICATION CHURCH AND THE RAJNEESH MOVEMENT ${ }^{1}$ AND THEIR \\ DEVELOPMENT OVER TIME ${ }^{2}$}

Liselotte Frisk, Professor Religious Studies, Högskolan Dalarna University, Sweden

\section{Introduction}

There have been few research projects in Sweden dealing with new religious movements. One notable exception, however, was the research project funded by Riksbankens Jubileumsfond between the years 2004-2007, which resulted in the book, published in Swedish, De nya religiösa rörelserna - vart tog de vägen? En studie av Scientologi-kyrkan, Guds Barn, Hare Krishna-rörelsen, Moon-rörelsen och Bhagwan-rörelsen och deras utveckling över tid (Nora: Nya Doxa 2007). This chapter is a summary of that book. There have been continual changes in these movements since 2007, but as this paper is intended to be a summary of the project no attempt is in this paper made to cover the years after 2007.

The project dealt with five new religious movements which became both wellknown and controversial during the 1960s and 70s. During the last decades, however, they have not been in the headlines as much as before. The project described how these movements have changed since their inception. The focus was on the decades after 1980, and there was a certain geographical emphasis on the Western world and Sweden.

Except for academic and emic literature, the primary material consisted of interviews (conducted between 2003 and 2007) with people who had been involved in these

\footnotetext{
${ }^{1}$ Several of the movements have changed names one or more times. In the title I use the names they were known by during the 1960 s and 70 s.

${ }^{2}$ This book was published in Swedish in 2007 with contribution from Riksbankens Jubileumsfond.
} 
movements for many years. Some of them were, at the time of the interview, still engaged in the movements, while others had left them. No references are provided when information considered "common knowledge" about these movements is mentioned, but rather only when the information is considered either specific or controversial. All materials used are listed at the end of the chapter.

The basic theme in the project was change. Religious change could be seen from a macro perspective, as the mere existence of new religious movements is part of a new pluralistic situation and therefore represents an aspect of change. But religious movements themselves also change over time. New religious movements, especially, demonstrate often interesting and dramatic developments with many changes during their first decades. The project discusses from a comparative perspective questions like the death of the charismatic leader and different solutions concerning the subsequent leadership, as well as the process of institutionalization. The development of the movements is discussed in light of traditional sociological theories about the development of religious organizations over time.

Today the general situation is much more pluralistic and multicultural than during the 1960s and 70s. New religious movements are generally not conceived of as being as deviant as they once were, as there are now many new and alternative phenomena in the culture. Increased immigration is one of the factors behind this change. There is today a societal tolerance for the fact that religion can express itself in several different ways and generate different ways of life. Contributing to this development has been the general increase of individualism in Western society, which has meant an increased conception of the individual as an active agent.

The very first anti-cult organization, Freecog (Free the Children of God), formed in the USA in 1972, was soon followed by several organizations all over the world. The 
Swedish organization, FRI (Föreningen Rädda Individen), was formed in 1984. The 1970s and 80 s were pervaded by heated debates about brainwashing and mind control, and many members of new religious movements all over the world were subjected to attempts at deprogramming. During the 90 s the debate became more moderate, and deprogramming was replaced by exit counseling. There has even been a tendency to promote dialogue between the anti-cult movement and the new religious movements. In Sweden, FRI has been replaced by Hjälpkällan, which has a more moderate approach (Åkerbäck 2012: 179-210).

An important event for several of the new religious movements was the fall of the iron curtain and communism in 1989. This event opened up a new mission area, and the post-communistic countries have been an important area of expansion for these movements as their proselytizing in other Western countries had seemed to stagnate.

This chapter will first summarize the developments of the five movements, in the order of the year in which they arrived to Sweden. The development of these movements are presented through a structure of different time periods, constructed individually for each movement. Sociological themes are focused on, as there is no space to present historical and ideological backgrounds. After this first section, the development of these movements will be thematically compared, analyzed and related to certain sociological theoretical perspectives.

\section{The Church of Scientology}

The Church of Scientology came to Sweden in 1969. After some reflection, I decided to divide the history of the Church of Scientology into four time periods. The first time period began in 1954, when the Church of Scientology was founded, and ended in 1966 when the spiritual leader L. Ron Hubbard withdrew from the outward leadership of the organization. As early as 1950, Hubbard had published one of the most important books in Scientology, 
Dianetics: The Modern Science of Mental Health. His theories were not appreciated by the psychiatry of those days, which laid the foundation for conflicts with psychiatry - conflicts which characterizes the group even today. An important reason for Hubbard to initiate the Church of Scientology in 1954 was to bring to an end the challenges from other groups and potential leaders practicing and teaching dianetics in the preceding years (Wallis 1977: 4950). This first period is characterized by strong expansion and also by controversies with society concerning doubts about the religious status of Scientology and possible fraud (quackery) concerning dianetics. During this period Hubbard also developed the organizational structure of Scientology in some detail.

The second period runs from 1967 to 1986, when Hubbard died. His death did not affect the church much, as the leadership in form of an administrative board was already in place. In 1967 one of the church's most important organizations, the Sea Org, was established. This organization was intended for advanced members who wanted to engage full-time in the organization and live austere lives of a monastic kind. In the beginning of the 2000s, approximately 7,000 people were members of the Sea Org (Melton 2001). This time period is also characterized by intense expansion and conflicts with society, though the latter were diminishing toward the end of the period. In Sweden there was significant negative publicity during the 80 s, particularly involving some Scientologists who had borrowed money from banks to pay the fees for advanced courses, and then either could not or did not want to pay back the loans.

The third time period from 1987 to 2000 was characterized by diminishing conflicts with society (with some exceptions), especially towards the end of that period. In several countries the Church of Scientology secured status as a religious organization. In 1993 Scientology was recognized as a religion in USA, and in 2000 Scientology was registered as a religious denomination in Sweden. 
After the year 2000 Scientology continues to expand according to internal sources. This expansion is, however, not visible in Sweden, at least not by 2007 when this research project ended. One reason may be that the church in Stockholm does not offer advanced courses, which is a reason for many interested persons to move abroad.

\section{The Children of God - The Family International}

The Children of God came to Sweden in 1971. This group's development has been divided into four time periods. During the first period, between 1968 and 1978, the group formed around the charismatic leader, David Berg, who was conceptualized as the endtime prophet. As the group grew, personal contact with the leader decreased and was replaced by the so called MO-letters which David Berg wrote to his disciples. The period is characterized by development from a small group around the charismatic leader to a full-time movement engaged in a tense relationship with society.

In 1978, the beginning of the second time period, Berg reorganized the group completely, fired the leaders and introduced a low-profile organization. All communes were encouraged to elect their own leaders. Communes became smaller and some members lived alone or in nuclear families. During this period the practice of sexuality became increasingly liberalized (a development that had already begun in the early 1970s), expressed as, for example, the habit of "sharing" in which adult members could have sexual relations with several people if there was mutual consent, and "flirty fishing," proselytizing through sexual relations. In 1981 Berg again strengthened the organizational structure.

During the third time period, 1981-1994, members again started to live together in bigger communes. Sexual freedom increased even more in the beginning of the $80 \mathrm{~s}$, eventually causing problems such as accusations of the abuse of children. In Sweden, there 
was an investigation of the sexual abuse of children in 1994. However, the group was found not guilty (as in most places in the world). During this time the number of children increased dramatically in the group, which also changed their orientation towards child care and home schooling.

In 1994 David Berg died. Since then his widow Maria and her new husband Peter are heading the organization. They are both considered prophets and maintain contact with members through letters. David Berg is also considered to be playing a role in the group by guiding them from the spirit world (Chancellor 2000: 26). The group has organizationally and ideologically increasingly developed toward becoming more mainstream. They work with mission and welfare projects, often in developing countries. The second generation - those who stayed in the organization -is often involved in these projects.

In Sweden there are only a handful of members.

\section{International Society for Krishna Consciousness (ISKCON)}

ISKCON came to Sweden in 1973. The development of ISKCON is divided into five time periods. The first one, between 1965-1977, starts with Bhaktivedanta Swami's arrival in New York in 1965, and ends with his death in 1977. Formally, ISKCON began in 1966. From a modest beginning as a small exotic movement gathered around a charismatic leader, by the end of the 1960s the movement had developed into a fulltime movement, living in large temple communities containing space for monks, nuns and married couples. The beginning of this time period was characterized by expansion on several levels. Sankirtana - chanting the Hare Krishna mantra publicly and distributing literature - recruited many members and generated economic resources. The anti-cult movement, however, grew stronger in the early 1970 's, which was one reason for the decline of the movement after the middle of the 1970's. 
The second time period, 1977-1987, was characterized by problems with finding a functioning leadership structure. Bhaktivedanta Swami had established a board structure for ISKCON in 1970, the Governing Body Commission (GBC), consisting of twenty men. Before his death he made clear that eleven of these would initiate disciples, and, if they were qualified, they would become gurus in their own right. The result was an increasing tension between the administrative and the spiritual leadership, which - together with several gurus' breaking the basic principles of the movement, and some gurus challenging the others for total leadership - led to many problems. There were also charismatic leaders from the wider Vaishnavitic religious scene, external to ISKCON, attracting some defectors. After Bhaktivedanta's death, the initiating gurus had divided up the world into different 'guru zones.' In Sweden, the local leaders had to leave ISKCON in the wake of a schism led by the European zone's guru, Harikesha Swami (Sjöblom 1990).

The third time period, 1987-1998, is characterized by the impact of a reform movement, which emphasized that guruship need not be restricted to the eleven men chosen by Bhaktivedanta Swami. The GBC decided that everyone seen as qualified by the GBC could be a guru. The gurus, however, were subordinated to the GBC. It was also made clear that Bhaktivedanta Swami occupied a special position. By 1998, there were around seventy gurus in the movement. This period was also characterized by many children being born into the movement, and severe tensions between the monks/nuns and the families. In some countries communities for families were started, some with their own schools. In Sweden the farm Almviks gård was purchased in 1982. Some families moved there, but some also moved out of the temples into their own apartments and started working secular jobs. ISKCON gradually became more of a part-time denomination. In Sweden there was an important change in the middle of the 1990s, when Almviks gård changed from being a spiritual community with shared resources to a village where everyone was supposed to take care of 
their own needs. The reasons were, as elsewhere, economic. From the beginning of the 1990's ISKCON also started to proselytize among migrants from Indian backgrounds.

In Sweden 1998 was an important year for ISKCON because the initiating guru for northern Europe since 1977, Harikesha Swami, was excluded from his position by GBC because of "physical and mental illness." That year thus starts the fourth period for the movement, 1998-2000. Harikesha Swami suffered from a breakdown, and also broke the basic principle of celibacy (as some of the other gurus also did).This problem was a great shock to his disciples. Most members in Sweden were initiated by him, and at least half of his disciples left the organization. Others, according to interviews, had doubts but finally decided to stay in the movement. Some of them chose a new guru, but most did not. As they were once initiated, they were linked to the succession although the initiator was not in the movement any more.

The fifth period started in 2000 and continued at least to the end of this project in 2007. This period was characterized by an inward orientation, which attempted to strengthen and consolidate the people already engaged in the movement rather than proselytizing to outsiders. There was, however, a new group of members who had never lived in the communities. It is difficult to determine how many people are engaged, as the borders between members and non-members are floating. There is a clear development in ISKCON from belief in authority and fulltime engagement in the organization towards individualism and part-time engagement. The tensions with society have decreased and are today almost nonexistent. 
A member of the Unification Church came to Sweden in 1969 to proselytize, but the first Swedish members joined the group in 1973. I have divided the development of this group into four time periods. After its inception in Korea in 1954, the first time period lasted until 1973, and is characterized by slow and gradual expansion. The movement early had international ambitions, and members were sent to Japan and to the USA as early as 1959 to proselytize. An important event for the group was the wedding between the founder, Sun Myung Moon, and Hak Ja Han in 1960. The couple is considered the True Parents by members, which has great religious significance.

In 1974 Sun Myung Moon moved to USA, an event which starts the second time period that lasted until 1991. In the beginning of the 70s Moon reorganized the movement and strengthened his position as leader. The expansion of the movement increased from the beginning of the 1970s, but it was not until Moon moved to USA that the expansion really took off, especially in USA but also in other countries. In Korea the movement functioned as an ordinary congregation with members living in society, but in the West members lived in celibacy in separate communes, waiting for the Blessing, the marriage which is considered the most important event in life. In the West, participation in the movement became a fulltime engagement, with members spending their days witnessing and fundraising.

The third time period, 1991-1996, is characterized by a development towards part-time engagement. One important factor was that many children were born in the movement during the $80 \mathrm{~s}$, as the members became older and had experienced the Blessing. The first child in Sweden was born in 1983. As the group emphasizes family values and the religious importance of marriage and having children, nuclear families were given even higher priority than before. Economic reasons also contributed to a change of lifestyle, as parents had to start working outside the movement to support their children. From 1991 and 
forward, Rev. Moon explicitly encouraged members with families to return to their own countries and serve their own family instead of the greater world.

Since 1996, the Unification Church has gone through radical changes. Rev. Moon initiated a change of name to Family Federation for World Peace and Unification, indicating that the movement should no longer be considered a church. The emphasis is now on three themes: family, peace and interreligious cooperation. The other (more challenging) ideological characteristics of the Unification Church have become less important. Different independent organizations have been formed to pursue the three themes. Swedish members point out that Rev. Moon's main mission was always more of uniting different churches than creating a new one, and that a new phase of the group has now begun. They are positive regarding the change as Sweden is a quite secular society, and think that a movement promoting certain ideals may be more successful than a church. To work for family, peace and interreligious cooperation is seen as way of implementing religious ideals in practice.

\section{The Bhagwan Shree Rajneesh/Osho movement}

The development of the Osho ${ }^{3}$ movement (earlier called the Bhagwan movement or the Rajneesh movement) has been divided into five time periods. The first period started in 1970 in Mumbai, when Osho initiated his first disciples. At that time he lived in an apartment together with a few close disciples. As more people came to listen to his lectures, the apartment became too small.

The second period began in 1974, when the movement bought land in Pune to build an ashram. By the end of the 70s, around 25,000-35,000 people were visiting yearly,

\footnotetext{
${ }^{3}$ To avoid confusion I will use the name Osho throughout the article.
} 
and about 3,000-5,000 people lived there (Carter 1990: 58). As the teaching of Osho was controversial in Indian culture (Osho talked against established values and religions, and promoted sexual freedom), there were soon tensions between the ashram and the local population. The borders between the ashram and the larger society were sharpened, and the movement gradually became more authoritarian. The Pune period ended in 1981 when Osho moved to USA to start a commune in Oregon.

The third period thus started in 1981 with the Oregon commune, Rajneeshpuram, and ended in 1985 when the commune collapsed. These years were characterized by a tremendous amount of work with the aim of building a town in the desert. Here tensions with the locals also became intense. The movement had major problems with the law as well, partly because the land was not scheduled for constructing a town and partly because Osho had not stated his intention of staying in US when he entered. The movement tried different aggressive strategies to survive. In 1985, the commune ended with some of the disciples being sentenced to jail and Osho being expelled from USA.

In 1987 Osho returned to Pune, and the fourth period started then and lasted until his death in 1990. The movement was now more oriented towards the individual and meditation, and most of the big communes had dissolved.

Osho died in 1990. Before he died, he appointed a group of 21 sannyasins, The Inner Circle, to handle the administrative tasks of the commune in Pune. As Osho had no successor, one might have expected that Osho as a person would be elevated after his death. But instead the tendency has been to downplay him in the movement, probably as a deliberate attempt to prevent the rise of an institutionalized religion (Fox 2000: 41-42). There has also been a development outside the institutionalized movement, in which some senior disciples of Osho have claimed enlightenment and have occupied charismatic positions (Frisk 2002). 
There is currently no formal center in Sweden, but there are several independent institutions with courses that are strongly influenced by Osho's thinking and that attract many people. One such institute is Baravara in Dalarna, which has about 1,000 visitors yearly. Through these institutes there are several new initiated disciples, but the strong individualistic orientation of the movement remains.

\section{Charisma, institutionalization and the death of the charismatic leader}

Most new religious movements are formed around a person who expresses a new teaching, a new interpretation of an older teaching, or a mixture of several older teachings. Usually this person occupies a very special position in the group. He or she is conceived of as having a special relationship with the divine or with a spiritual dimension, which legitimates his special position and authority. Often this person is called "charismatic." Max Weber defines the concept "charisma" as a special quality in a person, by virtue of which he is set apart from ordinary men and treated as endowed with supernatural, superhuman, or at least specifically exceptional powers of qualities. What is important is how the individual is regarded by his followers or disciples (Weber 1964: 358-9).

The charismatic leader's position and role looks different in specific groups, as the ideology is different and the leader's position is therefore legitimated in various ways. As the leader occupies such a special position in the movement, there is often a critical period after his death. New forms of authority and leadership have to be developed. Possibilities for ideological change decrease, as change is often based on the original leader's revelations. Additionally, a structured organization usually occupies more space than before - the movement is "institutionalized." This development, however, often already begins during the lifetime of the charismatic leader. 
Max Weber saw charisma and institutionalization as opposite processes.

Charisma challenges all institutions, as charisma tends to change, undermine and destroy them (1968: 51-52). Charismatic authority is, however, unstable and can only be upheld during a relatively short period (1968: 22). Weber calls the process when charisma is transformed into a permanent structure or organization the routinization of charisma. To a certain extent, the charismatic character is transmitted from being a unique person into a structured institution (1964: 363-73). This often happens when interests in social and economic security begin to predominate among the followers, a process that is often strengthened when the charismatic leader dies (1968: 54-55). Weber talks about the charisma of the office and hereditary charisma as examples of how charisma might, to a certain extent, stay with the organization (1964: 369-70). Weber also differentiates between three ideal types of authority and how these different forms of authority are legitimated: charismatic authority (discussed above), rational-legal authority, in which authority is legitimated through a system of rules, and the traditional authority, in which authority is legitimated through traditions and habits (1968: 46).

In the early 1980s, the sociologist of religion Roy Wallis analyzed the processes of charisma and institutionalization, based on empirical material from The Children of God (The Family International). He argued that the process of institutionalization was already initiated during a charismatic leader's lifetime, and that it is common that new religious movements oscillate between charisma and institutionalization. Wallis suggests that there are four different options for a leader to take in response to the institutionalization process: acquiescence (despite the limitations the institutionalization process causes), encouragement (developing and actively controlling the process), displacement (the leader does not understand that his authority is undermined and that the control of the movement has moved to the administrative leaders), and resistance (actively trying to halt the institutionalization 
process by continually changing the teaching, practice and administrative leaders) (Wallis 1982).

In the Church of Scientology, L. Ron Hubbard is conceived of as a liberated thetan, and thus definitely a person with exceptional qualities. Hubbard actively encouraged institutionalization of his religion very early, as a rational and effective organization is inherent in the teaching. Hubbard early withdrew from the organization, and his charisma was to a great extent routinized in his teachings, techniques, and organization. In Weber's terms, authority in the church moved from charismatic to rational-legal long before Hubbard's death. As this was the case, his death did not much affect the church.

David Berg was, for the members of Children of God/Family International, considered a prophet, and his teaching was seen as revealed by God. The teaching might, however, always be changed by new revelations, and Berg's teaching has been modified after his death. During Berg's lifetime the group oscillated between charisma and institutionalization, as Berg sometimes encouraged charismatic renewal and sometimes institutionalization. An example of charismatic renewal occurred when 1978 he almost dissolved the organization. After his death the movement has become more institutionalized and different parts of the movement are led by different boards. The charismatic leadership has partly been transmitted to his wife Maria, even if she does not have the same status as Berg. The authority in the movement is thus a mixture: partly the charismatic authority is routinized in an office, and partly the authority is rational-legal.

The founder of ISKCON, Bhaktivedanta Swami, had a very strong charismatic position. According to the Vaishnava tradition, the guru should be viewed as God by the disciples (Sardella 2005). Traditionally, a Hindu guru should appoint a successor during his lifetime, thus transmitting charisma to an office. Bhaktivedanta Swami, however, attempted to 
apply a mixture of a rational-legal and a charismatic structure in his appointment of the GBC and the eleven spiritual gurus, which could maybe also be called traditional authority as the guru office is legitimated by a succession of gurus for generations back. The movement was, however, challenged by both internal and external charismatic gurus. After the guru reform there were several gurus in the movement, but with less power and status than before, and Bhaktivedanta Swami's position as well as the position of GBC has been strengthened.

In the Unification Church there are two historical persons who have a unique spiritual position: Jesus and Rev. Moon. The position of Moon is thus very strong. Rev. Moon died after the completion of this research project - in 2012 - but already before his death his wife and some of his children were engaged in the leadership of the movement. It seemed that the group might adopt a kind of hereditary charisma, which would make sense with the group's emphasis on the family. The group has undergone several significant changes over time, initiated by Moon. Possibly these changes could be seen as attempts at charismatic renewal. Most of the changes have, however, been orientated towards institutionalization and the encouragement of part time engagement, at the same time as children and family life increased in the group.

Bhagwan Shree Rajneesh (Osho) always had a unique position in the Osho movement. He had no guru succession behind him as had Bhaktivedanta Swami, and no successor after him. His position in the movement has, however, varied over time, and was partially deemphasized after 1985. In the two communes in Pune and Oregon the institutionalization process was encouraged, as no communes could be built without it, but Osho also used several methods for charismatic renewal, as he often changed his teaching and the positions of members. The institutionalization process reached a peak in Oregon in the middle of the $80 \mathrm{~s}$, when criminal acts were carried out. After Osho's death the group was led by a board, thus making the authority structure rational-legal. In the 90 s and early 2000 s the 
movement was challenged by external charisma. On one level the Osho movement is today quite institutionalized, with the same rules applying to all Osho centers around the world, but on another level there is a resistance towards institutionalization which is also seen in developments outside the movement.

\section{Changes in organizational form}

The classification of religious organizations into the categories cult, sect, denomination, and church is basic to the sociology of religion. The discussion in this context will be based on the representation of these categories by Meredith B. McGuire (2002). For a more thorough discussion than space allows in this article, see Frisk 2007.

Two important criteria for McGuire, which have also historically been key themes in the classification of religious organizations, are degree of tension to society and degree of self-conceived legitimacy. According to McGuire's representation, churches consider themselves uniquely legitimate and exist in a positive relationship with society, while sectarian groups also consider themselves to be uniquely legitimate, but are in a relatively negative relationship with the dominant society. Sects typically also emphasize high levels of commitment. Denominations have a positive relationship with society and, having a pluralistic approach, accept the legitimacy claims of other religious groups. Cults are characterized by acceptance of the legitimacy claims of other groups and exist in relatively negative tension with the larger society. Their social dissent is, however, likely to be less extreme because of their pluralistic stance (McGuire 2002: 155-158).

Religious organizations change over time. There are standard directions for this change, although there might be other possibilities as well. Cultic groups are more unstable than other types of religious organizations, because of their indistinct and pluralistic doctrine, 
their problem of authority and the individualistic and segmental mode of commitment. The typical transformation for a cult is to develop in the direction of becoming a sect. The key feature in this transformation is the arrogation of authority. The leader successfully claims strong authority, clarifying the boundaries of the group belief system and membership. The most common change for sectarian organizations is a change towards becoming a denomination through the routinization of charisma. Sectarian groups become denominations by giving up their claim to exclusive legitimacy and by reducing their tension to society. Many cultic groups first become more sectarian, and later move towards becoming denominations (McGuire 2002: 177-181).

The Church of Scientology displays a typical example of the change from cult to sect. Hubbard created a foundation for dianetics in 1950, but simultaneously there existed other practitioners of dianetics, some of whom wanted to change parts of the practice and also combine it with other teachings, thus displaying the typical pluralistic legitimacy and the unclear authority associated with a cult. The Church of Scientology, founded in 1954, was more authoritarian and more controlled by Hubbard, and also demanded higher degrees of engagement. Dianetics already had a certain tension with society, but this tension increased immensely in the following decades, as Scientology challenged the mainstream culture in different ways. In part, the ideology of Scientology has also encouraged increased tension with society, as the strategy has been to attack enemies rather than to compromise. This was an important reason for the fact that the high tension with society was maintained for several decades. Since the 90s the group has, however, developed towards becoming a denomination. The tensions with society have diminished as the church has been acknowledged as a religion in several countries. The arrival of children does not seem to have influenced the church much, probably because the main part of the membership have always been engaged parttime. 
The Children of God/Family International also started as a cult, but soon the tension with society increased and the group developed towards becoming a sect. By the beginning of the 1970s, the borders between the group and the mainstream society had already become sharper, and the tension with society increased even more when the ideology was radicalized. By the end of the 80 s, however, the group was approaching society again. One reason for this change was that the tension with society had become too high, and the relationship to society was close to a collapse because of the accusations of child abuse. In this situation, the group was more or less forced to change. This coincides with a time when the second generation numerically started to dominate the movement. In the case of The Family International, it is clear that the demographic change of increasing numbers of children in the movement has been of great importance for the development of the movement. Beginning in 1995, it was also possible to be engaged part time (for further development after the completion of this research project, see Nilsson 2011).

For the first few years ISKCON was a loosely structured cult around Bhaktivedanta Swami, becoming a fulltime sect with a communal living and a rising tension towards society by the end of the 1960 s. From the middle or end of the 1980 s the tension with society gradually diminished. This change also coincided with a changed demographic profile. Around 1990 nuclear families had replaced the communities as ISKCON's base. For economic reasons families had to live in society and support themselves. Part time engagement thus became common, which also decreased tensions with society. This development has continued during the latter years, making the group move towards a denominational status. ISKCON has also deliberately tried to decrease tensions with society through, for example, approaching and getting Hindu migrants involved.

The Unification Church was a small cult for a long time, until it started to grow in the 1970 s and there were changes towards a sectarian status. Tension with society 
increased, with the, for the mainstream, challenging ideology of Rev. Moon as the new Messiah and the controversial practice of arranged marriages. After children started to arrive during the 1980s, there was a gradual development towards part-time engagement. Beginning in 1991, Rev. Moon encouraged members to live in nuclear families. Since 1996 there have been further changes in the direction of a non-controversial movement working for family values, peace and interreligious work. It might even be said that the movement is moving from being a denomination towards becoming more of a secular organization or a cultural movement. However, the group still works as a religious denomination for segments of its members. It seems that both orientations operate side by side.

Bhagwan Shree Rajneesh (Osho) started his movement as a cult, moving towards a sect status in 1974 when the ashram in Pune was initiated. The borders with society were sharpened, charismatic authority increased and tensions with society rose. One reason for this development was the ideology of the movement, which challenged the norms and traditions of mainstream society, and the controversial habit of teaching through provocation. Since 1985 the group has developed in the direction of denominational status, with part-time engagement and a low degree of tension with society. In this particular group, tensions with society increased to the point of collapse. A difference from the other groups investigated in this chapter is that there were few second generation members as this group did not encourage having children.

\section{Conclusion}

There is a clear pattern of organizational change as all five movements closely followed classic organization development from cult to sect to denomination. All movements have with time, though in somewhat different ways, approached society and are less controversial 
than they were. Most changed from full time to part-time engagement (except the Church of Scientology, where both possibilities have been an option especially? since the inception of Sea Org in 1967). Also, all changed from a charismatic to, at least partly, a rational-legal structure. The different types of changes seem to reinforce one another.

In three of the groups the most important reason for the change toward part-time engagement was the arrival of children - the second generation - a development that also changed the economic situation of members. This development is not seen in either the Church of Scientology or the Osho movement. In two of the movements - The Family International and the Osho movement - the tension with society increased until the relationship more or less collapsed. As the tension was no longer functional, the two groups went through radical changes and the tension with society decreased dramatically.

In four of the movements (the Unification Church being the exception) the first charismatic leader died before the completion of the research project, which could also be one factor in decreasing tension with society. A living charismatic leader continually changes and radicalizes teachings as part of charismatic renewal. After his death, there are fewer changes in a movement.

Another factor which is important for the development of the relationship with society is the ideological orientation of the movements. In some cases - as in the case of Scientology - the tension with society was upheld for a long time due to ideological reasons. Also in the Osho movement, ideological characteristics intensified tensions to society.

After the death of the first charismatic leader, the different movements chose very different leadership solutions. Some of the movements were challenged by internal and external charisma. The institutionalization process started early in all movements, but developed in different ways, dependent partly on ideological factors. The institutionalization 
process generally began while the charismatic leader was alive, but was intensified after his death. An important factor is how the charismatic leader reacts to the institutionalization process, by encouragement or resistance. A typical example of encouragement is the Church of Scientology.

The Church of Scientology seems to have developed in a slightly different way compared to the other four movements. If we are to believe internal sources, the church is still growing on a global level. Important factors for this development might be that the church has an economic base which is stronger than the other groups (the economic policy of the church has been widely criticized), as well as a well-functioning organization and ideological support for emphasizing the mission, and the view of growth and progress as spiritual qualities. However, the Church of Scientology has little possibility of changing, as its form is highly institutionalized, which might in the future be a disadvantage as society changes.

None of these five groups is growing today in Sweden, though some of them claim to have experienced growth in Eastern European countries or in the third world. An important question is what will happen when the first generation disappears. Some of the groups may (more or less) disappear as organizations, and only remain as cultural impulses. This does not necessarily mean that the movements will become unimportant. The Theosophical Society, for example, is today tiny as an organization, but has had an enormous influence on the contemporary New Age movement. Thus there is a possibility of remaining important as a cultural impulse, despite shrinking or disappearing as an organization.

\section{Bibliography}

Printed material 
Bainbridge, William Sims. 2002. The Endtime Family: Children of God. Albany: State University of New York Press.

Barker, Eileen. 1993. The Making of a Moonie. Choice or Brainwashing? Aldershot, Hampshire: Gregg Revivals.

Beverly, James A. 2005. “Spirit Revelation and the Unification Church.” In J. R. Lewis and J. Aagaard Petersen, eds, Controversial New Religions. Oxford: Oxford University Press, 43-59.

Carter, Lewis F. 1990. Charisma and Control in Rajneeshpuram: The Role of Shared Values in the Creation of a Community. Cambridge: Cambridge University Press.

Chancellor, James D. 2000. Life in the Family: An Oral History of The Children of God. New York: Syracuse University Press.

Christensen, Dorthe Refslund. 1997. Scientology. Fra terapi till religion. Köpenhamn: Gyldendal.

--- 1999. Rethinking Scientology: Conition and Representation in Religion, Therapy and Soteriologi. Aarhus: University of Aarhus.

Chryssides, George D. 1991. The Advent of Sun Myung Moon: The Origin, Beliefs and Practices of the Unification Church. London: Macmillan.

--- 2004. “Unificationism: A Study in Religious Syncretism.” In S. Sutcliffe, ed., Religion: Empirical Studies. Aldershot: Ashgate, 231-244.

D'Andrea, Anthony Fischer. 2007. “Osho International Meditation Resort (Pune 2000): An Anthropological analysis of Sannyasin Therapies and the Rajneesh Legacy.” Journal of Humanistic Psychology. 47: 1, 1-26. 
Fox, Judith M. 2000. Osho Rajneesh. Studies in Contemporary Religion. Torino: US:

Signature Books in cooperation with CESNUR.

Frisk, Liselotte. 1998. Nyreligiositet i Sverige: Ett religionsvetenskapligt perspektiv. Nora: Nya Doxa.

--- 2002.”The Satsang Network: A growing post-Osho Phenomenon. “ Nova Religio. 6: 1, 64-85.

--- 2007. De nya religiösa rörelserna - vart tog de vägen? En studie av Scientologi-kyrkan, Guds Barn, Hare Krishna-rörelsen, Moon-rörelsen och Bhagwan-rörelsen och deras utveckling över tid. Nora: Nya Doxa.

Goldman, Marion S. 2005. "When Leaders Dissolve: Considering Controversy and Stagnation in the Osho RAjneesh Movement.” In J. R. Lewis and J. Aagaard Petersen, eds, Controversial New Religions. Oxford: Oxford University Press, 119-137.

The Hare Krishna Movement: The Postcharismatic Fate of a Religious Transplant. 2004. Eds E. F. Bryant and M. Ekstrand. New York: Columbia University Press.

Introvigne, Massimo. 2000. The Unification Church. Studies in Contemporary Religion. Series editor: Massimo Introvigne. US: Signature Books in cooperation with CESNUR. McGuire, Meredith. 2002. Religion: The Social Context. Belmont, California: Wadsworth Publishing Company.

Melton, J. Gordon. 2000. The Church of Scientology. Studies in Contemporary Religion. US: Signature Books in Cooperation with CESNUR.

--- 2004. The Children of God: “The Family”. Studies in Contemporary Religion. Series editor Massimo Introvigne. US: Signature Books in cooperation with CESNUR. 
Nilsson, Sanja. 2011. "Rebooting the Family: Organizational Change Within The Family International." International Journal for the Study of New Religions, 2:2, 157-178.

Sardella, Ferdinando. 2005. "Neither Man nor God.” Finyar Arsskrift, vol. 2, 76-93.

Sex, Slander and Salvation: Investigating The Family/Children of God. 1994. Eds. J. R. Lewis and J. G. Melton. Stanford, California: Center for Academic Publication.

Sheela. 1996. Tötet ihn nicht! München: Walter Shinagl.

Sjöblom, Ronny. 1990. "When the Master Dies: Conflict and Development within the Swedish ISKCON.” In N. G. Holm, ed., Encounter with India: Studies in Neohinduism. Åbo: Åbo Akademi, 61-78.

Squarcini, Federico and Fizzotti, Eugenio. 2003. Hare Krishna. Studies in Contemporary Religion. US: Signature Books.

Wallis, Roy.1977. The Road to Total Freedom: A Sociological Analysis of Scientology. New York: Columbia University Press.

--- 1982. “Charisma, Commitment and Control in a New Religious Movement.” In R. Wallis, ed., Millennialism and Charisma. Belfast: The Queen's University, 73-140.

Weber, Max, 1964. The Theory of Social and Economic Organization. Edited and with an introduction by Talcott Parsons. New York: The Free Press.

--- 1968. On Charisma and Institution Building. Selected Papers. Edited and with an introduction by S. N. Eisenstadt. Chicago and London: The University of Chicago Press.

Åkerbäck, Peter. 2012. "Tänk på barnen: Om barn, hjärntvätt och politisering av sekter.” Aura: Tidskrift för akademiska studier av nyreligiositet, vol. 4, 179-210. 
Unprinted material

Amsterdam, Peter. 2004. "The Family - Restructuring and Renewal: An Overview of

Organizational Changes." Unpublished article presented at CESNURs conference in Waco, Texas, 17-20 June 2004.

Melton, J. Gordon. 2001. “The Sea Org: A Report of Research on a Contemporary Ordered Religious Community." Unpublished article presented at CESNURs international conference at London School of Economics, London, 19-21 April 2001.

Interviews 